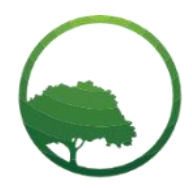

Research in Business \& Social Science

IJRBS VOL 10 NO 4 ISSN: 2147-4478

\title{
The effect of Islamic intellectual capital, corporate governance, and corporate social responsibility disclosure on maqashid sharia performance, with reputation as a moderating variable
}

\author{
(D) Siti Aisyah ${ }^{(a)}$ (D) Bambang Hariadi (b) (iD) Endang Mardiati ${ }^{(c)}$ \\ ${ }^{(a)}$ Accounting Department, Faculty of Economics and Business, University of Brawijaya, Malang, Indonesia \\ ${ }^{(b, c)}$ Assoc. Prof(s)., Accounting Department, Faculty of Economics and Business, University of Brawijaya, Malang, Indonesia
}

\author{
A R T I CLE INFO \\ Article history: \\ Received 18 May 2021 \\ Received in rev. form 09 June 2021 \\ Accepted 11 June 2021 \\ Keywords: \\ Maqashid Syariah Performance, \\ Islamic Intellectual Capital, Corporate \\ Governance, Corporate Social \\ Responsibility Disclosure, Reputation \\ JEL Classification: \\ G21, P47
}

\begin{abstract}
A B S T R A C T
This study aims to show that there is a positive relationship between Islamic intellectual capital, corporate governance, disclosure of corporate social responsibility on the performance of maqashid sharia, and this study wants to show that reputation strengthens this positive relationship. This study's sample consists of 33 annual reports from 11 Islamic banking companies in Indonesia for the 20162018 period, chosen using the purposive sampling method.This study was tested by using the Moderated Regression Analysis test. The results of this study indicate that Islamic intellectual capital, corporate governance, disclosure of corporate social responsibility have a negative effect on the performance of Islamic maqashid. The role of reputation can not increase the relationship of Islamic intellectual capital to the performance of maqashid sharia. Reputation also can not increase the relationship of disclosure of corporate social responsibility to the performance of maqashid sharia, but reputation has been proven to improve the relationship of corporate governance to the performance of maqashid sharia. The results of this study are input for the Financial Services Authority (OJK) and Bank Indonesia (BI) as regulators to monitor the performance of Islamic financial institutions in order to protect the public interest as a whole.
\end{abstract}

(C) 2021 by the authors. Licensee SSBFNET, Istanbul, Turkey. This article is an open access article distributed under the terms and conditions of the Creative Commons Attribution (CC BY) license (http://creativecommons.org/licenses/by/4.0/).

\section{Introduction}

The development of Islamic financial institutions in Indonesia is currently quite fast and is starting to be in demand by the public, especially Muslims. One of the Islamic financial institutions in Indonesia is Islamic banking. The development of Islamic banks in Indonesia makes competition between banks more competitive. Not only is there competition between Islamic banks and conventional banks, but there is also fierce competition among Islamic banks. Circumstances like this make Islamic banks have to work harder to improve performance. The better the bank's performance will increase public confidence in the bank concerned. The performance of a bank can be analyzed through financial statements. Financial statement analysis helps to assess the performance of a bank by using financial ratio analysis. According to Muljono (2009), the performance of Islamic banking can be calculated by calculating the soundness of the bank based on ratio criteria such as liquidity ratios, profitability ratios, solvency ratios.

The financial performance of Islamic banks as measured by the calculation of the conventional method is considered less representative of the conditions of Islamic banking. Calculations with conventional methods are actually incomplete when used to assess the performance of Islamic banks. Other calculations are needed to measure bank performance in terms of sharia. Research conducted by Dzikri (2016) shows that the calculation of performance in accordance with Islamic bank operations is by using the Maqashid Sharia Index. The Maqashid Sharia Index is calculated not only from a sharia perspective, but also from a financial ratio

* Corresponding author. ORCID ID: 0000-0002-1699-4981

(C) 2021 by the authors. Hosting by SSBFNET. Peer review under responsibility of Center for Strategic Studies in Business and Finance.

https://doi.org/10.20525/ijrbs.v10i4.1233 
perspective. Performance measurement in terms of sharia, such as measuring social performance, measuring sharia compliance (sharia compliance), or measuring performance based on maqashid sharia.

The banking sector is an intellectually intensive business sector. This means that customer service is highly dependent on the intellect/intelligence of human capital. Success in producing the best performance must of course be supported by the presence of human resources who have high knowledge.

This is supported by changes in economic conditions in the world, making knowledge of human resources (knowledge-based industries) a major factor in the sustainability of the company's current competition (Maisaroh, 2015). Human capital is one of the components of intangible assets which, if managed properly will improve the company's performance. This is known as intellectual capital. Companies can increase competitive advantage by developing resources so that they are able to direct the company to survive in the long term (Thaib, 2013). Research conducted by Isanzu (2015) examines the impact of intellectual capital on the financial performance of banks in Tanzania which proves that intellectual capital has a positive relationship with financial performance. Bustamam and Aditia (2016) who examined 11 Islamic banks in Indonesia which showed that intellectual capital had an effect on profitability. However, several studies showed different results such as Basuki and Sianipar (2012), Firrer and Williams (2003), Lestari, et al. (2013).

The Intellectual capital assessment method with value added intellectual coefficient (VAIC) is an assessment method for conventional companies (private sector, profit motive, and non-sharia) (Ulum, 2013). Islamic banks are different from conventional banks, therefore the formula for calculating income and expenses is also different. Ulum (2013) reconstructed the intellectual capital assessment method for Islamic banking, namely the Islamic banking value added intellectual coefficient (iB-VAIC). Based on this research, the researchers chose the measurement method compiled by Ulum (2013), namely measuring intellectual capital (IC) with Islamic banking value added intellectual coefficient (iB-VAIC). This is because the method is described more specifically for income and expenses. Islamic bank income and expenses are different from conventional bank expenses. Therefore, the calculation formulation is also different, and the naming for the measurement of intellectual capital is more appropriate to using Islamic intellectual capital (IIC).

Corporate governance, in addition to Islamic intellectual capital, is a system management banking designed to improve bank performance, protect stakeholders, and improve compliance with laws, regulations, and generally accepted ethical values.Therefore, in building public trust, it is necessary to implement GCG as a condition for developing well and health (Zarkasyi, 2008). In the GCG mechanism of sharia banks, it is necessary to establish a sharia supervisory board (DPS) to regulate sharia banks so that their business activities are in accordance with sharia principles. Then the supervisory DPS provides recommendations to the board of directors, to be followed up. It is the duty of the board of commissioners to ensure that the findings or recommendations of the DPS have been followed up by the directors of Islamic banks (Hanif, 2018). The results of research by Kholid and Bachtiar (2014) found that the board of commissioners had a positive effect on the performance of Maqashid sharia, the audit committee had a negative effect on the performance of Maqashid sharia, and the sharia supervisory board had no effect on the performance of maqashid sharia.

Islamic banks as entities that run their business activities based on sharia principles are expected to make ethical values and social responsibility a part of their business model (Haniffa, 2002). Corporate social responsibility is part of fulfilling the company's responsibility to the community and stakeholders. Meanwhile, one way to communicate corporate social responsibility information to stakeholders is through disclosure in the annual report. Disclosure of corporate social responsibility plays an important role in showing the form of corporate ethical accountability in assisting stakeholders in their decision making (Hassan and Harahap, 2010). Companies in general in the disclosure of corporate social responsibility using the global reporting initiative (GRI). However, as sharia-based companies develop, the use of indexes in the disclosure of corporate social responsibility in sharia-based companies needs to be adjusted, to make them more relevant (Abdul et al. 2017). According to (Haniffa 2002), argues that an index that is more relevant in the disclosure of corporate social responsibility for sharia-based companies is called the Islamic social reporting index (ISR). According to Istianah et al. (2015), the overall disclosure of social responsibility in the perspective of maqashid sharia based on the Islamic social reporting index is $61 \%$.The results of the research by Harapan et al. (2014) show that ISR has an influence on company profitability. In contrast to the findings of Amelia et al. (2010), CSR has no effect on company profitability.

Based on the explanation previously presented, the researcher found an inconsistency in the results of previous research. If this research gap raises an assumption that there are other factors that can strengthen or weaken the relationship between the influence of Islamic intellectual capital, corporate governance and disclosure of corporate social responsibility on the performance of Islamic maqashid with reputation as a moderating variable. Reputation as a moderating variable is expected to strengthen the influence of Islamic intellectual capital, corporate governance and disclosure of corporate social responsibility on the performance of Islamic maqashid. Reputation is considered as a signaling effort by the company to reduce information asymmetry (Sharpe and Ivana 2005). Many large companies disclose this additional information in order to give a signal to stakeholders about the activities they undertake to achieve their goals and what the company has done for the environment (Putri, 2014). The reputation of a company must be improved in the face of increasingly fierce business competition. According to Harpur (2002), reputation is a judgmental assessment of whether there is harmony between what the company says about itself and what society observes. This is related to the better reputation of an Islamic bank. The public trust in Islamic banks will automatically increase in line with the increasing performance of Islamic banks. 


\section{Literature Review}

\section{Resource Based Theory (RBT)}

This theory was first put forward by Wernerfelt (1984), resource-based theory is a theory that describes that companies can increase competitive advantage by developing resources so that they are able to direct companies to survive in the long term. The key to the RBT approach is understanding the strategy of understanding the relationship between resources, capabilities, competitive advantage, and profitability, specifically understanding the mechanism by which to maintain competitive advantage over time.Such a model requires the use of unique characteristic effects on the company (Ramadhan, 2017).

\section{Agency Theory}

Theory was originally introduced by Jensen and Meckling (1976). Agency theory explains the contractual relationship that occurs between the customer (principal) and the Islamic bank (agent). The purpose of agency theory is to evaluate and share the results according to the agreed employment contract. What should be avoided is information asymmetry, in which the bank's management has more information than the fund's owner.The owner of the fund aligns the objectives with the management so that there is no difference of interest.

\section{Stakeholder Theory}

Stakeholder theory was first developed by Freeman (1984), which defines stakeholders as a group of people or individuals who are identified as being able to influence the company's activities or can be influenced by the company's activities. The main emergence of stakeholder theory is to assist company management in enhancing the creation of value as a brand impact of activities.

\section{Signaling Theory}

This theory explains the existence of an imbalance in the ownership of information by managers and company stakeholders. Every individual or organization in a company has different access to information (Conelly et al., 2011). The purpose of this theory is to reduce the condition of information imbalance held by managers and other stakeholders (Spence, 2002). Managers need to convey this information that can be used as a signal to external parties. Interested parties will use this information to view and assess the condition of the company in the past, present, and to predict the company's future (Lesmana and Sukartha, 2017).

\section{Islamic Intellectual Capital and Maqashid Sharia Performance}

Intellectual capital is the knowledge contained in the company, but many companies do not realize that intellectual capital can manage the company's competitive advantage. In addition to managing a competitive advantage, companies are optimizing intellectual capital primarily for human resources, it will increase the value added (value added) of the company. Intellectual capital can increase the profits of companies whose profits are influenced by innovation and knowledge-intensive services (Hanif, 2018). There are many measurement methods for measuring intellectual capital, one of which is compiled by Ulum (2013), which reconstructs the measurement of intellectual capital with Islamic Intellectual Capital (IIC), the measurement of IIC is adjusted to income and also expenses for Islamic banks. The relationship between Islamic intellectual capital andperformance Islamic maqashidis shown by several studies including Thaib's research (2013) showing that the independent variables of value-added capital employed (VACA), value added human capital (VAHU), and structural capital value added (STVA), have an influence positively on return on assets (ROA), at 4 state banks. Harianto and Syafruddin (2013) show that the higher the company's IC value, the higher the company's future performance will be, so logically, the growth rate of IC will also be correlated with future performance. However, there are several studies that show different results, such as research by Rachmawati (2012) which also shows that VAHU is negative and does not have a significant effect on profitability. Banking companies tend to use physical capital rather than using intangible capital, namely human capital. Wijaya's research (2012) shows that the components of VAHU and STVA and DER have no effect on ROE. Based on theoretical considerations and previous research, researchers predict the occurrence of a positive influence between intellectual capital and the performance of Islamic banking companies. Based on this explanation, the hypothesis can be proposed:

\section{H1: Islamic intellectual capital has a positive effect on maqashid sharia performance}

\section{Corporate Governance and Maqashid Sharia Performance}

Implementation of corporate governance will reduce agency problems that occur, and is considered to be able to improve the banking image, protect the interests of stakeholders and improve compliance with applicable laws and regulations and general ethics in the banking industry in order to create a sound banking system. Sunarwan's research (2019) states that the board of commissioners has a significant effect on the financial performance of Islamic banking. The results of Ghaffar's research (2014) also show that there is a significant relationship between CGD and financial performance (ROA-ROE). In contrast to the Jannah Research (2019), the results show that not all structures in GCG have a significant effect on the performance of independent Islamic banks. Arumsari (2014), which shows the results that GCG has no effect on company performance. Based on theoretical considerations and previous research, the researcher predicts a positive influence between companies that implement corporate governance and the performance of Islamic banking companies. Thus, the hypothesis of this research is:

H2: Corporate governance has a positive effect on maqashid sharia performance. 


\section{Corporate Social Responsibility and Maqashid Sharia Performance}

Companies that want to have sustainability in their business must pay attention to the "3P", namely the planet, people, and profit. Such as the concept of the triple bottom line, in which a company, in addition to pursuing profit, considers the welfare of the community (people) and actively contributes to the preservation of nature (the planet).Gustani's research (2017), finds that ICSR has a significant influence on the performance of Islamic banking companies in QISMUT countries. Anshori (2018) claims that ICSRan has an impact on company performance based on Islamicity. In contrast to the findings of Mosaid and Boutti (2012), there is no significant relationship between CSR disclosure and the financial performance of Islamic banks.Based on theoretical considerations and previous research, the researcher predicts a positive influence between companies that disclose corporate social responsibility and the performance of Islamic banking companies. Based on this explanation, a hypothesis can be proposed:

\section{H3: Corporate social responsibility has a positive effect on maqashid sharia performance}

\section{The Moderating Role of Reputation on the Effect of Islamic Intellectual Capital on Maqashid Sharia Performance}

Human capital efficiency (HCE) is the main driver of a company's reputation. Companies that want a good reputation need to increase attention to human resources, strategies for assessing knowledge, skills, employee experience, and good relationships with customers are the main factors in obtaining a company reputation (Ginesti et al., 2018). Research by Widanaputra et al. (2018) shows that the use of all assets by the company can greatly affect the company's reputation, including intellectual capital being an important element in it. If a company cannot manage its tangible or intangible assets, it will affect the consistency of the company's reputation. Rossendhy's research (2015) found that the company's reputation has the ability to strengthen the influence of intellectual capital on company performance. This is different from the research conducted by Nimtrakon (2015) which found that there was no significant effect of IC on company performance and company reputation. Based on the explanation above, the hypothesis of this research is stated as follows:

\section{H4: Reputation strengthens the influence of Islamic intellectual capital on maqashid sharia performance}

\section{The Moderation Role of Reputation on the Effect of Corporate Governance on Maqashid Sharia Performance}

Banking must be able to reflect that it is also good in order to achieve a good reputation from the community. With a good reputation, the sustainability of a business will also be good. Corporate governance is thought to be capable of improving the image of the banking industry, protecting the interests of stakeholders, and improving compliance with applicable laws and regulations, as well as general ethics in the banking industry, in order to create a healthy banking system (Dewayanto, 2010). Junusi's research (2012) shows the results that the implementation of sharia governance has an effect on the reputation and trust of customers which is directly related to the financial performance of Islamic banks. According to Kapilah's (2019) research, Islamic corporate social responsibility, reputation, and shariah governance all have an impact on the performance of Islamic banks. In contrast to the results of research conducted by Syam and Najda (2012), in their research explains that the quality of good GCG implementation in Islamic commercial banks does not affect the rate of return and has a negative effect on reputation and performance. Based on the explanation above, the hypothesis of this research is stated as follows:

\section{H5: Reputation strengthens the influence of corporate governance on maqashid sharia performance}

The Moderation Role of Reputation on the Effect of Corporate Social Responsibility Disclosure on Maqashid Sharia Performance

Practice and disclosure of corporate CSR is one of the positive information that will affect the company's support stakeholders. Of course, if a company receives support and a positive impression from stakeholders, the company's reputation will improve.The more CSR practices carried out by the company, the reputation of the company will increase (Humanitisri, and Ghozali, 2018). Research by Fombrun and Shanley (1990) states that if a company pays attention to social interests such as charitable donations, developing products that do not cause pollution, providing equal opportunities to employees, forming foundations, and other activities related to social and environmental issues, the company will gain a good name. or goodwill from its stakeholders, it will increase the company's profitability in the long term. Lestari's research (2018) shows the results that there is a positive and significant relationship between ICSR, zakat and the company's reputation and profitability. In contrast to research by Arifin and Wardani (2016), it shows that Islamic corporate social responsibility (ICSR) has no effect on the reputation and performance of the company when measured by ROA. Based on the explanation above, the hypothesis of this research is stated as follows:

H6: Reputation strengthens the effect of corporate social responsibility disclosure on maqashid sharia performance 


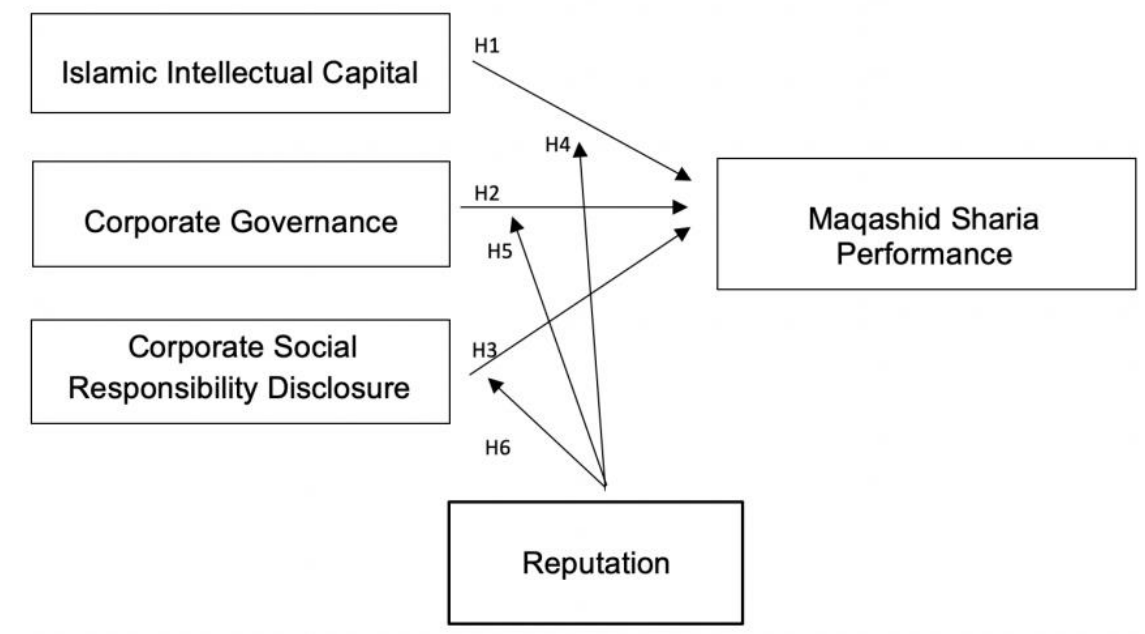

Figure 1: Research Model

\section{Research and Methodology}

This study examines the effect of Islamic intellectual capital, corporate governance, and disclosure of corporate social responsibility on the performance of Islamic maqashid and the role of reputation as a moderating variable. The analysis used in this research is quantitative analysis. The population in this study is Islamic Commercial Banks in Indonesia. This study's sample was drawn using a judgment-based purposive sampling technique.The criteria for consideration of sample selection in this study are:

i. Sharia Commercial Banks listed on the Indonesia Stock Exchange for the 2016-2018 period, respectively.

ii. Islamic Commercial Banks that publish an annual report from 2016 to 2018 that contains the data required for the study.

The population in this study amounted to 13 Islamic commercial banks, and the sample in this study was 33 annual reports from 11 Islamic banking companies.

\section{Operational Definition and Measurement of Variables}

The variables used in this study include the independent variables, namely Islamic intellectual capital, corporate governance and disclosure of corporate social responsibility, the dependent variable, namely the performance of sharia maqashid, and the moderating variable, namely reputation.

\section{Dependent Variable}

Variable The dependent variable in this study is the performance of maqashid sharia. The word maqashid is the plural form of maqshad which means intent and purpose, while shari'ah has the meaning of God's laws that are set for humans to be guided to achieve happiness in life in this world and in the hereafter (Shidiq et al., 2009). In this study, performance is measured using the maqashid sharia index (MSI).

$$
\mathrm{MSI}=\mathrm{IK}(\mathrm{V} 1)+\mathrm{IK}(\mathrm{V} 2)+\mathrm{IK}(\mathrm{V} 3)
$$

Description:

$\mathrm{IK}(\mathrm{V} 1)=$ Performance indicator of goals maqashid education

IK $(\mathrm{V} 2)=$ Performance indicator of goals of maqashid justice

$\mathrm{IK}(\mathrm{V} 3)=$ Performance indicator of goals maqashid welfare

\section{Independent Variable}

\section{Islamic Intellectual Capital}

Islamic intellectual capital is knowledge, information and intellectual property that is able to find opportunities and manage threats in the life of a company, so that it can affect resilience and competitive advantage in various ways (Nugroho, 2012). The IIC measurement model in this study uses the IB-VAIC (Islamic banking value added intellectual capital coefficient) compiled by Ulum (2013) with the following formula:

Calculating IB-Value Added (IB-VA)

\section{iB-VA = OUT-IN}


Description:

OUT = Output, total revenue/ net income of sharia activities

IN = Input, operating/operational expenses and non-operational expenses except for personnel/employee expenses

Calculating the Value Added of Islamic Banking Capital Employed (iB-VACA)

\section{iB-VACA $=$ VA/CE}

Description:

iB-VACA = Value Added Capital Employed

$\mathrm{VA}=$ Value Added

$\mathrm{CE}=$ Capital Employed; total equity

Calculating the Islamic Banking Value Added Human Capital (iB-VAHU)

iB-VAHU = VA/HC

Description:

iB-VAHU = Value Added Human Capital

VA $\quad=$ Value Added

HC $\quad$ = Human Capital; employee expenses

Calculating the Islamic Banking Structural Capital Value Added (iB-STVA)

\section{iB-STVA = SC/VA}

Description:

iB-STVA= Stuctural Capital Value Added

VA $\quad=$ Value Added

$\mathrm{SC} \quad=$ Structural Capital; $\mathrm{VA}-\mathrm{HC}$

Calculating the Islamic Banking Value Added Intellectual Coefficient (iB-VAIC ${ }^{\mathrm{TM}}$ )

iB-VAICTM = iB-VACA + iB-VAHU + iB-STVA

\section{Corporate Governance}

Corporate governance is a system within the company that regulates and controls to create added value for all stakeholders. In this study, to calculate corporate governance (GCG) which is proxied by the number of meetings of the board of commissioners and directors in Islamic commercial banks.

\section{Corporate Social Responsibility Disclosure}

Corporate social responsibility is a continuous commitment from the business community to behave ethically and contribute to economic development to improve the quality of life for employees, local communities and society at large. The CSR measurement model in this study uses Islamic social reporting (ISR) developed by Haniffa (2002).

$$
\mathrm{ISR}=\frac{\text { number of items disclosed }}{\text { total number of disclosure items }} \times 100 \%
$$

\section{Moderation Variables}

Variable The moderating variable used in this study is reputation. Dowling (1994) defines a company's reputation as the result of an evaluation (assessment) that describes the company's image according to the public. The company reputation measurement model in this study uses a third party fund (TPF) proxy (Reskino, 2016).

$$
\mathrm{REP}=\frac{\mathrm{TPF} \text { Bank }}{\text { Total TPF in the market }} \mathrm{VS} \frac{100 \%}{\text { Total BUS and UUS }}
$$

\section{Data Analysis Model}

Test the hypothesis using moderated regression analysis (MRA), namely the multiplication between the independent variables and their moderation. The analysis technique used is the hierarchical regression analysis method. This regression model must pass the classical assumption test, including normality test, heteroscedasticity test, multicollinearity and autocorrelation. The test is carried out by:

$$
\mathrm{Y}=\alpha+\beta 1 . \mathrm{X} 1+\beta 2 . \mathrm{X} 2+\beta 3 . \mathrm{X} 3+€ .
$$
(model 1) 


$$
\begin{gathered}
\mathrm{Y}=\alpha+\beta 1 . \mathrm{X} 1+\beta 2 . \mathrm{X} 2+\beta 3 . \mathrm{X} 3+\beta 4 . \mathrm{X} 4+€ \ldots \ldots \ldots \ldots \ldots \ldots \ldots \ldots \ldots \ldots \ldots \ldots \ldots \ldots \ldots \ldots \ldots \ldots \ldots . . .(\text { model } 2) \\
\mathrm{Y}=\alpha+\beta 1 . \mathrm{X} 1+\beta 2 . \mathrm{X} 2+\beta 3 . \mathrm{X} 3+\beta 4 . \mathrm{X} 4+\beta 5 . \mathrm{X} 1 . \mathrm{X} 4+\beta 6 . \mathrm{X} 2 . \mathrm{X} 4+\beta 7 . \mathrm{X} 3 . \mathrm{X} 4+€ \ldots \ldots .(\text { model } 3)
\end{gathered}
$$

Description:

$\begin{array}{ll}\mathrm{Y} & =\text { Maqashid Sharia Performance } \\ \alpha & =\text { Constant } \\ \beta 1, \beta 2, \beta 3, \beta 4, \beta 5, \beta 6, \beta 7 & =\text { Regression Coefficient } \\ \mathrm{X} 1 & =\text { Islamic Intellectual Capital } \\ \mathrm{X} 2 & =\text { Corporate Governance } \\ \mathrm{X} 3 & =\text { Corporate Social Responsibility Disclosure } \\ \mathrm{X} 4 & =\text { Reputation } \\ € & =\text { Error }\end{array}$

\section{Results and Discussion}

The results of the Descriptive Statistical Analysis are shown in Table 1

Table 1: Descriptive Statistics

\begin{tabular}{llllll}
\hline & N & Minimum & Maximum & Average & Std. Deviation \\
\hline IIC & 33 & $-2,12$ & 4,01 & 2,0361 & 1,17604 \\
\hline CG & 33 & 7,00 & 36,00 & 14,303 & 6,24242 \\
\hline CSR & 33 & 0,77 & 0,95 & 0,8555 & 0,06142 \\
\hline MS & 33 & 0,12 & 0,39 & 0,2525 & 0,05459 \\
\hline REP & 33 & 0,00 & 1,00 & 0,4545 & 0,50565 \\
\hline
\end{tabular}

From the results of the descriptive statistical test presented in table 1 on Islamic intellectual capital as measured by iB-VAICTM shows an average value of 2.0361. This shows that the performance of banking in Indonesia during the period 2016 to 2018 is in the category of good performers. Corporate governance as proxied by the number of meetings of the board of commissioners and directors shows an average value of 14, this indicates that the average Islamic banking company in Indonesia conducts board of commissioners and directors meetings 14 times a year. Disclosure of corporate social responsibility as measured using the Islamic social reporting index (ISR) shows an average value of 0.8555 , this indicates that the average sample companies of Islamic banking have disclosed ISR items of $85.6 \%$. The maqashid sharia index (MSI) shows an average value of 0.2525 , indicating that the performance of the Maqashid Sharia Index (MSI) in the sample companies of Islamic banking is classified as quite good with a percentage of $25.25 . \%$ of all indicators of education, justice, and welfare. The value of the standard deviation of the variables of Islamic intellectual capital, corporate governance, disclosure of corporate social responsibility, andperformance Islamic maqashid which is below the average indicates that the deviation of the sample data is relatively small. Reputation proxied by third party funds (TPF) shows an average value of 0.4545 , and a standard deviation of 0.50565 . The standard deviation value which is higher than the average value indicates that the level of deviation of the sample data that occurs is also relatively high. This is because as many as 18 or $54.5 \%$ of the reputations of the sample companies of Islamic banking received a bad predicate (code 0) during the period 2016 to 2018 , while 15 or $45.5 \%$ of the reputations of the sample companies of Islamic banking received a good predicate (code 1 ) during the period 2016 to 2018 .

\section{The results of Regression Analysis}

Hypothesis 1 model 1, which tests the positive relationship between Islamic intellectual capital and maqashid sharia performance, yields a negative beta value of -0.004 , a t of -0.466 , and a significance of $0.678(0.678>0.05$, indicating that hypothesis 1 is rejected).These results prove that Islamic intellectual capital has no effect on the performance of maqashid sharia. Testing hypothesis 2 model 1, which tests the positive relationship between corporate governance and maqashid sharia performance, has a negative beta value of- 0.003 , and t of- 2.21 with a significance of $0.983(0.983>0.05$ so it is not significant $)$ so that hypothesis 2 is rejected. These results prove that corporate governance has no effect on the performance of maqashid sharia. The results of hypothesis testing 3 model 1 , which tests the positive relationship between corporate social responsibility and sharia maahid performance, have a negative beta value of- 0.24 , $t$ of -1.633 , and a significance of 0.944 ( $0.944>0.05$, so it is not), indicating that hypothesis 3 is rejected.This shows that there is no influence of the corporate social responsibility variable on the performance of maqashid sharia.

The direct influence of the reputation moderation variable on the performance of maqashid sharia in model 2 shows a positive coefficient value of $0.010, t$ of 0.564 with a significance value of $0.289(0.289>0.05$ so it is not significant). So that the reputation variable directly does not affect the performance of maqashid sharia. This means that the reputation variable cannot be an independent variable. 
Hypothesis testing 4 model 3 which tests the moderating role of reputation on the influence of Islamic intellectual capital on maqashid sharia performance and the results of MOD1 show a negative coefficient value of $-6.36 \mathrm{E}-05$ and a t test value of -1.141 with a significance level of $0.868(0.868>0,05$ so it is not significant) so that hypothesis 4 is rejected. These results prove that reputation can not moderate the influence of Islamic intellectual capital on the performance of Islamic maqashid. Hypothesis 5 examines the moderating role of reputation on the influence of corporate governance on maqashid sharia performance and the results of MOD2 show a positive coefficient value of 0.009 and a t-test value of 3.331 with a significance level of 0.0015 ( $0.0015<0.05$ so significant $)$ so that hypothesis 5 be accepted. These results prove that reputation strengthens the influence of corporate governance on the performance of maqashid sharia. Hypothesis 6 examines the moderating role of reputation on the effect of corporate social responsibility disclosure on maqashid sharia performance and the results of MOD3 show a positive coefficient value of 1.73E-05, and a t-test value of 0.361 with a significance level of $0.361(0.361>0.05$ so it is not significant $)$ so that hypothesis 6 is rejected. These results prove that reputation can not moderate the effect of corporate social responsibility disclosure on maqashid sharia performance. In this study, the reputation variable is a pure moderating variable because reputation can not be an independent and significant variable when it is moderated. The results of the regression analysis that have passed the classical assumption test are shown in table 2

Table 2: Results of Regression Analysis

\begin{tabular}{|c|c|c|c|c|c|c|}
\hline Model & Variable & Beta Coefficient & $\mathbf{T}$ & Sig. & $\operatorname{Adj} R^{2}$ & Test \\
\hline \multirow[t]{4}{*}{ Model 1} & $\begin{array}{l}\text { Constant } \\
(\alpha)\end{array}$ & 0,513 & & & 0,144 & \\
\hline & IIC & $-0,004$ & $-0,466$ & 0,678 & & Hypothesis1 \\
\hline & CG & $-0,003$ & $-2,21$ & 0,983 & & Hypothesis2 \\
\hline & CSR & $-0,243$ & $-1,633$ & 0,944 & & Hypothesis3 \\
\hline \multirow[t]{5}{*}{ Model 2} & $\begin{array}{l}\text { Constant } \\
(\alpha)\end{array}$ & 0,508 & & & 0,123 & \\
\hline & IIC & $-0,004$ & $-0,548$ & 0,706 & & \\
\hline & CG & $-0,003$ & $-2,009$ & 0,973 & & \\
\hline & CSR & $-0,244$ & $-1,62$ & 0,942 & & \\
\hline & REP & 0,01 & 0,564 & 0,289 & & \\
\hline \multirow[t]{8}{*}{ Model 3} & $\begin{array}{l}\text { Constant } \\
(\alpha)\end{array}$ & 0,669 & & & 0,325 & \\
\hline & IIC & $-0,012$ & $-1,48$ & 0,925 & & \\
\hline & CG & $-0,006$ & $-3,773$ & 0,10 & & \\
\hline & CSR & $-0,354$ & $-2,089$ & 0,977 & & \\
\hline & REP & $-0,124$ & $-2,818$ & 0,996 & & \\
\hline & MOD1 & $-6,36 \mathrm{E}-05$ & $-1,141$ & 0,868 & & Hypothesis4 \\
\hline & MOD2 & 0,009 & 3,331 & 0,0015 & & Hypothesis5 \\
\hline & MOD3 & $1,73 \mathrm{E}-05$ & 0,361 & 0,361 & & Hypothesis6 \\
\hline
\end{tabular}

Description of variables: Islamic Intellectual Capital (IIC), Corporate Governance (CG), Disclosure of Corporate Social Responsibility (CSR), Performance of Maqashid Syariah (MS), Reputation (REP), Interaction of Islamic Intellectual Capital variables with Reputation (MOD1), Interaction of Corporate variables Governance with Reputation (MOD2), and Interaction of Corporate Social Responsibility Disclosure with Reputation (MOD3).

\section{Conclusions}

The results of this study found empirical evidence that Islamic intellectual capital is not one of the factors that can affect the performance of maqashid sharia. This is because Islamic banking companies in Indonesia have not optimally managed and developed their intellectual property to win the competition (competitive advantage) or improve the performance of Islamic maqashid, and have not become an interesting theme to be developed in order to improve company performance. The company still focuses a lot on shortterm interests, namely increasing financial returns.

The results of this study also found that corporate governance is not another factor that can affect the performance of Islamic maqashid. This is because the number of meetings of the board of commissioners and directors is too high, it does not guarantee that the company's performance will be better. The results of this study also found that the performance of sharia maqashid was not influenced by the disclosure of corporate social responsibility. The low performance of maqashid sharia occurs because several sharia banking companies have not set aside funds for zakat, funds have not been allocated for educational grants, and the funds distributed are still dominated by consumptive murabahah funds compared to mudharabah and musyarakah funds which are for investment. This study found that the influence of Islamic intellectual capital on the performance of Islamic maqashid can not be moderated by reputation. Not all Islamic banking companies provide training funds to their employees on an ongoing basis. The results of this 
study found empirical evidence that reputation is a factor that can strengthen the role of corporate governance in the performance of Islamic maqashid. This is because the existence of DPS as a supervisor will make Islamic banks in operational activities and in launching products more compliant with sharia principles. If management in the view of stakeholders is considered good, then the reputation risk will be low. This study also found that the effect of corporate social responsibility disclosure on the performance of Islamic maqashid cannot be moderated by reputation. Distribution of CSR funds that are not well targeted or in this case, only focused on certain groups who are recipients of funds, causes the low reputation of Islamic banks in the eyes of the wider community. A low reputation will greatly affect the performance of banking companies as a whole.

\section{References}

Abdullah, Dewi Fariha, and Sauda Sofian. 2015. The Relationship between Intellectual Capital and Corporate Performance. Procedia - Social and Behavioral Sciences 40. https://doi.org/10.1016/j.sbspro.2012.03.227

Amaroh. 2016. Social responsibility of Islamic banks to stakeholders in the perspective of maqashid sharia. Ahkam, Vol.16, No.1. https://doi.org/10.15408/ajis.v16i1.2894

Arshad, R., and Othman, S. 2012. Islamic corporate social responsibility, corporate reputation and performance. International Journal of social, Behavioral, Educational, Economic, Business and Industrial Engineering Vol:6, No:4. https://doi.org/10.5281/zenodo.1074857

Bontis, N., Chua Chong Keow, W., \& Richardson, S, 2000, Intellectual capital and business performance in Malaysian industries. Journal of intellectual capital, 1(1), 85-100. https://doi.org/10.1108/14691930010324188

Chapra, Umer. 2011. Vision of Islam in Economic Development: According to: Maqashid Ash-Sharia. Translated: Ikhwan Abidin Basri. Solo: Al Hambra.

Dowling, G. 1994. Corporate reputations: Strategic for developing the corporate brand. London: Kogan Page. https://www.worldcat.org/title/corporate-reputations-strategies-for-developing-the-corporate-brand/oclc/315921747

Dzikri, Muhammad. 2016. Performance Analysis of Bank Muamalat Indonesia and Bank Syariah Mandiri in terms of Maqashid Syariah and Intellectual Capital. Journal of Islamic Economics. URI: http://digilib.uin-suka.ac.id/id/eprint/23430

Freeman, RE 1983. Strategic Management: A Stakeholder Approach. Boston, MA: Pitman Press. https://www.worldcat.org/title/strategic-management-a-stakeholderapproach/oclc/9685996

Gustani. 2017. Analysis of the Effect of Disclosure of Islamic Corporate Governance (ICG) and Islamic Corporate Social Responsibility (ICSR) on Market Discipline with Financial Performance as an Intervening Variable. (Empirical Study on Islamic Banks in QISMUT Countries). Scientific Journal of Accounting: Compartments. Vol 15 (02). https://www.serialsjournals.com/abstract/46550_11.pdf

Haniffa, R., 2002. Social Reporting Disclosure: An Islamic Perspective. Indonesian Management and accounting Research, 128-146. https://kitlv-docs.library.leiden.edu/open/345610423.pdf

Hanif, Hernawan. 2018. The Influence of Islamic Intellectual Capital on the Performance of Maqashid Syariah with Corporate Governance as Moderating Variable. URI: https://dspace.uii.ac.id/handle/123456789/7839

Hartono, Nono. 2017. Analysis of the Effect of Islamic Corporate Governance (ICG) and Intellectual Capital (IC) on the Maqashid Syariah Index (MSI) in Islamic Banking in Indonesia. Al-Amwal Journal. Vol 10 (02). https://doi.org/10.24235/amwal.v10i2.3249

Isanzu, Janeth N. 2015. Impact of Intellectual Capital on Financial Performance of Banks in Tanzania. Journal of International Business Research and Marketing. Volume 1, Issue 1. https://doi.org/10.18775/jibrm.1849-8558.2015.11.3002

Jensen, Michael C. and William H. Meckling. 1976. Theory of the Firm: Managerial Behavior, Agency Costs and Ownership Structure. Journal of Financial Economics. 3(4), pp. 305-360.

https://doi.org/10.1016/0304-405X(76)90026-X

Khalid Muammar Nur. 2015. Good Corporate Governance and Performance of Islamic Maqashid Syariah Banks in Indonesia. JAAI, Vol 19, No. 2. https://doi.org/10.20885/jaai.vol19.iss2.art4

Mohammed, Mustafa Omar \& Taib, Fauziah Md. 2015. Developing Islamic Banking Performance Measures Based On Maqasid AlShari'ah Framework: Case of 24 Selected Banks, Journal of Islamic Monetary Economics and Finance, p. 5577. https://doi.org/10.21098/jimf.v1i1.483

Nugroho, A. 2012. Factors Affecting Intellectual Capital Disclosure (ICD). Accounting Analysis Journal, 1(2). https://doi.org/10.15294/aaj.v1i2.702

Pulic, A. 1998. Measuring the performance of intellectual potential in the knowledge economy. Paper presented at the 2nd McMaster World Congress on Measuring and Managing Intellectual Capital by the Austrian Team for Intellectual Potential. https://www.semanticscholar.org/paper/Measuring-the-performance-of-intellectual-potentialPulic/708bebbe69caebcd281c5e18425cc645cee9816d

Purnomosidhi, B. 2006. The Practice of Disclosure of Intellectual Capital in Public Companies on the JSE. Indonesian Journal of Accounting Research. Vol 9, No. 1, 1-20. http://doi.org/10.33312/ijar.146

Ramadhan, Mohammad Iqbal Bagus, et al. 2018. Intellectual Capital and Performance of Islamic Maqashid Islamic Banking in Indonesia. Journal of Islamic Accounting and Finance. Volume 6 (1), p. 5-18. http://doi.org/10.35836/jakis.v6i1.6 
Rhamadhani, RF 2016. The effect of zakat on company performance (empirical study on Islamic commercial banks in Indonesia). $\begin{array}{lllll}\text { Journal of } & \text { Studia } & \text { Islamika, } & \text { 33(2), }\end{array}$ http://lib.ibs.ac.id/materi/Prosiding/SNA\%20XIX\%20(19)\%20Lampung\%202016/makalah/084.pdf

Sharpe (1997) and Ivana (2005), the announcement of accounting information gives a signal that the company has good prospects in the future (good news).

Shidiq, G. 2009. Maqashid Al-Sharia Theory in Islamic Law Maqashid al-Shari'ah, Sultan Agung Islamic University, XLIV(118), pp.117-130.

Sidik, I., \& Reskino. 2016. Zakat and Islamic Corporate Social Responsibility: Do these effect performance of sharia banks? Journal of Economics and Business, 1(2). http://doi.org/10.22515/shirkah.v1i2.23

Thaib, Faezal. 2013. Value Added Intellectual Capital (VAHU, VACA, STVA), Its Effect on the Financial Performance of Government Banks for the period 2007-2011. EMBA Journal, Volume 1. No. $03 . \quad$ Pg 153. https://doi.org/10.35794/emba.v1i3.1951

Ulum, Ihyaul. 2013. iB-VAIC: Model of Intellectual Capital Performance Measurement in Islamic Banking in Indonesia. Journal of Inference, volume 7, no 1. https://doi.org/10.18326/infs13.v7i1.185-206

Wernerfelt, B. 1984. A resource-based view of the firm. Strategic management journal. 5(2), 171180.http://links.jstor.org/sici?sici=01432095\%28198404\%2F06\%295\%3A2\%3C171\%3AARVOTF\%3E2.0.CO\%3B2-L

Publisher's Note: SSBFNET stays neutral with regard to jurisdictional claims in published maps and institutional affiliations.

\section{(a) (1)}

(C) 2021 by the authors. Licensee SSBFNET, Istanbul, Turkey. This article is an open access article distributed under the terms and conditions of the Creative Commons Attribution (CC BY) license (http://creativecommons.org/licenses/by/4.0/).

International Journal of Research in Business and Social Science (2147-4478) by SSBFNET is licensed under a Creative Commons Attribution 4.0 International License. 